\title{
Development of Integrated Thematic Student Worksheets (LKPD) Using the Discovery Learning Model in Class IV Elementary Schools
}

\author{
Silfi Melindawati ${ }^{1 *}$ \\ ${ }^{1}$ Lecture in PGSD STKIP ADZKIA, Sumatera Barat, Indonesia \\ * Corresponding Author: \\ Email: silvimelinda01@gmail.com
}

\begin{abstract}
.
This research is motivated because of the problems found in schools, namely, the LKPD used in schools is generally less attractive, both in terms of the space for filling in the less extensive answers, the color of the LKPD which does not have an attractive color, the structure is incomplete and the supporting images for the LKPD are inadequate. This research is a development research, namely Research and Development (R\&D) which consists of four stages, namely: define, design, development, disseminate. in this development research using the 4-D model proposed by Thiagarajan (in Ratumanan, 2019: 61). The results showed that the development of discovery learning-based LKPD collected through a validation questionnaire was used to measure the feasibility of student worksheets (LKPD). The results showed that the discovery learning-based student worksheets developed were feasible and valid for learning. This is evident from the results of obtaining questionnaires by expert experts and educators who state that the development product is feasible based on the results of the linguist expert's validity test (92.5\%) is categorized as very valid, aspects of rpp Validator 1 (92.5\%) are categorized as very valid, Validator $2(95.00 \%)$ which is categorized as very valid, expert design expert (98.07\%) is categorized as very valid. This proves that the Integrated Thematic Student Worksheet Development (LKPD) with the Discovery Learning Model in Class IV of Elementary School is stated very valid.
\end{abstract}

Keywords: LKPD, Discovery Learning, Thematic Integrated

\section{INTRODUCTION}

Since 2013/2014, the government has implemented a new curriculum called the 2013 Curriculum. This curriculum replaces the old curriculum, namely the Education Unit Level Curriculum (KTSP). The 2013 curriculum is a competencybased curriculum that emphasizes activity-based learning on affective aspects or behavior change. In its application, according to Nuh in Kurniasih and Berlin Sani in (Ratih \& Taufina, 2018)) "The 2013 curriculum emphasizes competence with competency thinking based on attitudes, skills and knowledge". In contrast to the 
previous curriculum which emphasizes the cognitive aspects of students. The competencies to be achieved are competences that are balanced between attitudes, skills and knowledge, as well as a holistic and fun way of learning.[1]

The 2013 curriculum has been applied to learning activities in elementary schools for grades I to VI carried out using integrated thematic learning. The 21st century learning paradigm emphasizes the ability of students to think critically, be able to connect knowledge with the real world, master information communication technology, and collaborate (Sulistyorini et al., 2018) [2]. The government designs 21st century learning through the 2013 curriculum that is student-based. Educators as the right hand of government in schools apply 4C capabilities (Critical Thinking, Communicaion, Callaboration, Creativity). According to (Rusman, 2015) [3] said that thematic learning is integrated meaningful because students will understand the concepts they learn through direct experience and relate them to other concepts that have been understood.

Learning activity as a process is a system that cannot be separated from the other components that interact with each other. The preparation of the learning process that is designed cannot be separated from the teaching materials used in each learning process, one of which is teaching materials, (Melindawati, 2019)[4]. According to (Prastowo, 2013) [5] teaching materials are a collection of teaching materials / materials that are arranged systematically so as to create an environment / atmosphere that allows students to learn. Meanwhile, according to (Kemendiknas, 2010) it explains that teaching materials are all forms of materials used to assist teachers in the learning process. Teaching materials are used for communication and interaction between educators and students in the learning process[6]. One example of teaching materials is the student activity sheet (LKPD) which is used to support the learning process in presenting subject matter. LKPD is often used to help students and educators in the learning process. LKPD acts as one of the learning media that should be made by subject experts or educators so that the content and learning objectives are achieved. The use of LKPD as a learning medium can help students in the learning process.

In addition, the implementation of learning in which there are experimental activities requires instructions or guidelines. The preparation of learning guidelines is intended to guide students in concept discovery activities. The learning guide should contain work steps that involve the thinking process, work procedures, and the independence of students to find concepts. Guidelines containing such activities are called Student Activity Sheets (LKPD) (Depdiknas, 2008)[7]

The advantage of having LKPD for educators is that it makes it easier for them to carry out learning. Then, students can learn independently to understand and carry out a written assignment. The benefits of drafting LKPD are to increase the involvement of students or activities of students in learning and change the learning conditions from teacher centered to student centered. Based on the advantages and benefits of the LKPD above, it can be concluded that the LKPD is a sheet containing 
tasks that must be done by students in learning, contains instructions or steps in completing tasks in accordance with Basic Competencies and indicators of achievement of learning outcomes that must be achieved (Abidin \& Utami, 2021)[8].

Based on the analysis of researchers in class IV SDN 38 Kampung Baru Nan XX Padang City on February 24, 25 2020, the methods used by educators at the time of learning were still using the lecture method, question and answer, discussion of information, and educators using LKPD that had not been made by the work of educators. themselves, but educators use it by buying LKPD from book print partners. It turns out that the LKPD used in elementary schools is not in accordance with the learning styles of students, and the LKPD used by educators has colors and images on the LKPD that are less attractive, the LKPD is made from newspapers which makes the LKPD used easily torn / torn when used by students, as well as space for students to fill in the answers to questions too narrow.

The learning styles of students are divided into three, namely visual, audio and kinesthetic. The learning style of students that the researcher has applied is a visual learning style that describes several characteristics, namely the need to see something visually to know or understand lesson information, and to have a strong sensitivity to color according to the age development of grade IVA elementary school students.

Discovery learning model is "a learning theory that is defined as a learning process that occurs when students are not presented with the lesson in its final form, but it is hoped that students will organize themselves and the educator will act as a guide by providing opportunities for students to learn actively, educators must be able to guide and directing the learning activities of students in accordance with the objectives. that has been determined and provides opportunities for students to find solutions to real problems that are around them, by developing discovery learningbased LKPD so that students can play an active role, and make conclusions from the learning material. (Kurniasih, 2014) [9]. Meanwhile, according to (Rosarina et al., 2016) discovery learning is a problem-solving model that will be useful for students in facing their future life [10].

The reason researchers use the discovery learning model is because of this discovery learning students can acquire knowledge individually so that it can be understood and deposited in their minds, (a) it can generate motivation and learning passion of students to study even harder, (b) provide opportunities to develop and progress according to their respective abilities and interests, (c) strengthening and increasing confidence in oneself with a self-discovery process, (d) involving the process of interaction between students, (e) educators and students, (f) as well as the environment and learning resources for the achievement of basic competencies. Through the discovery learning model, students become closer to what is the source of their learning, students' self-confidence will increase because they feel that what they 
International Journal Of Science, Technology \& Management

have understood is found by themselves, cooperation with their friends will increase, and of course add to the student experience (Putrayasa \& Syahruddin, 2014)[11].

\section{METHODS}

This study uses development research. Development research is a term often used for research and development methods which in English is called Research and Development (R\&D). According to Gray, et al (2009: 18) "Research and Development (R\&D) is the process of researching consumer needs and then developing products to fulfill those needs" . According to (Sugiono, 2010) Research and Development R\&D is a research method used to produce certain products and test the effectiveness of these products [12].

The development model used refers to the 4-D model, which was proposed by Thiagarajan. According to Thiagarajan (in Ratumanan, 2019: 61) this model consists of four stages, namely: define, design, develop, and disseminate or adapt it to a 4-D model, namely defining, designing, developing and disseminating [13].

\section{RESULT AND DISCUSSION}

The LKPD development research uses the Discovery Learning model using the 4D development model by Thiagrajan (Trianto, 2011) which consists of 4 development stages, including: define, design, development, disseminate[14]. At this stage of research, the author only carried out the development stage, the dissemination stage was not carried out due to time limitations and the current pandemic condition, namely COVID-19. The results of the LKPD development research using the Discovery Learning model in integrated thematic learning based on the research method used are as follows:

1. The definition stage (Define)

The defining stage analysis was carried out on several aspects including: curriculum analysis, LKPD analysis and student analysis. The following is a description of the results of the research at the definition stage.

a. Curriculum Analysis

The results of curriculum analysis are carried out to determine basic competencies (KD) and indicators that have been set in the 2013 curriculum content standards. The results of $\mathrm{KD}$ analysis and indicators are translated into indicators of learning achievement that will be achieved by students through discovery learning-based LKPD for grade IV elementary school students. .

b. LKPD analysis

LKPD in circulation is not in accordance with the learning style of students, namely less attractive colors, space for students to fill in too narrow answers, LKPD used in Elementary Schools uses newspaper that is easily penetrated and torn. Therefore, to increase the attractiveness and enthusiasm for students in learning aimed at elementary 
school students in grade IV for material on the theme of 8 areas where I live, subtheme 3 learning 1 .

\section{c. Student Analysis}

The characteristics of the students analyzed were elementary school class IV students in the 2019/2020 school year. Based on the analysis that the researchers conducted, the characteristics of the learning styles of grade IV elementary school students were: students in the learning process using LKPD did not see things visually to know or understand lesson information, and learning to use LKPD was colorless so that students were bored and lazy to do it.

Based on this analysis, it appears that it is necessary to use LKPD that can direct LKPD that can direct the curiosity and enthusiasm of students in learning. Likewise, the presentation of learning should be adjusted to the learning model used in the LKPD so that students do not feel bored during the learning process.

There are several problems above. LKPD using discovery learning models for students will be very appropriate to be learned in class. Using LKPD with discovery learning models will be able to increase the attractiveness and enthusiasm of learning of students.

\section{Design Stage (Design)}

The results of the defining stage (Define) are used as a basic stage for designing LKPD using the Discovery Learning model. Based on the analysis that the author has done at the define stage, LKPD is designed to use the Discovery Learning model on theme 8 , sub-theme 3.

\section{Development Stage (Development)}

At this stage of development, the authors develop LKPD and RPP, the finished products are completely validated by experts according to their fields. Vallidation aims to discuss LKPD using a valid Discovery Learning model so that it can be used in the learning process. From the results of the validation, revisions were made based on comments and suggestions by the expert validators. As for the results of making LKPD products, the results of RPP validation are as follows:

a. RPP and LKPD Product Development

\section{Learning Implementation Plan (RPP)}

The RPP is designed systematically which contains the components of RPP writing that have been regulated in Permendikbud number 22 of 2016 concerning the standard process and steps for preparing RPP. Learning activities are designed according to the Discovery Learning model. The purpose of designing this lesson plan is to guide the author in designing LKPD products.

\section{LKPD}

LKPD is adjusted to the $\mathrm{KI}$ and $\mathrm{KD}$ defined by the curriculum, then arranged according to the Discovery Learning learning model.

b. RPP and LKPD validation 
The RPP and LKPD that have been designed are then validated by the validator using validated instruments. Validation was carried out by 4 validators. In this activity, experts are asked to assess the RPP and LKPD for which the assessment has been designed including content, presentation, and language. The validator is asked to provide an assessment and suggestions for improvements to the RPP and LKPD that have been designed. RPP and LKPD have been revised and submitted back to the validator. The validator is asked to provide an assessment and opinion on the LKPD that has been designed. Validation has been completed when the validator has stated that the planned RPP and LKPD are valid and revised. The results of the RPP get a percentage of $95 \%$ in the very valid category, the material aspects get a percentage of $97.72 \%$ are in the very valid category, the language aspect gets a percentage of $92.25 \%$ is in the very valid category, the design aspect gets $98,07 \%$ are in the very valid category.

4.The Disseminate Stage (Spread)

At this stage is the distribution of products and testing the validity of LKPD conducted by researchers to be used by others. But at this stage it was only carried out until the development stage because this research was constrained by the Covid-19 epidemic which did not allow the author to go to the field.

The development of this LKPD refers to the 2013 curriculum analysis then a draft LKPD is produced using the Discovery Learning model in grade IV of Elementary School on Theme 8 (My Residence Area) Sub-Theme 3 (Proud of the Area I live in) which aims to help students to be able to learn more independently. In developing this student worksheet there are several steps that the writer must take so that this LKPD is valid to be used in the learning process.

This LKPD product development is made as a valid learning media. Thiagarajan (Trianto, 2012) explained that this study consisted of 4 stages of development, namely: define, design, development, and disseminate [15]. After the product has been developed, the LKPD is validated from the linguist, design, and material rpp. From the results of the assessment conducted by the validator, the resulting LKPD with a "very valid" average

The validity of the Integrated Thematic LKPD development using the Discovery Learning model in grade IV elementary schools

This study includes 4 aspects that are assessed by the validator to determine the validity of the LKPD using the Discovery Learning model. According to (Arikunto, 2009) "Validity is a measure that shows the level of validity of a test. A test is said to be valid if the test measures what it wants to measure. The test has high validity if the results match the criteria, in the sense that it has a parallel between the test and the criteria. [16]

The validation in this study consisted of aspects of the lesson plan, material, language, and design. Based on the results of the validation of the 3 aspects described above from 
the 4 vali dators, the overall validation of the LKPD using the Discovery Learning model that was developed was "very valid".

At this stage of validity, the assessed aspects include material aspects getting the average validation results with a very valid category. Based on the results of these data, it shows that the LKPD developed meets the criteria of "very valid" with an average overall aspect of $95.82 \%$ in accordance with the criteria for the level of validity according to Purwannto in (Lestari et al., 2018)[17]

Percentage (\%) Validation Criteria

$90 \%-100 \%$ Very valid

$80 \%-89 \%$ Valid

$65 \%-79 \%$ Quite valid

$55 \%$ - 64\% Less valid

$\leq 54 \%$ Very invalid

Based on the results of the data obtained, it can be seen that the LKPD developed has been in accordance with the material and rules of correct writing with sentences presented simply and clearly so that students are able to understand well-designed LKPD. The LKPD developed is in accordance with the model applied, namely Discovery Learning is a learning model that is easy to set, involves the activities of all students without having any status differences, involves the role of students as peer tutors and allows students to find new discoveries from the results they get., and the knowledge obtained is very personal and powerful because it strengthens the understanding and memory of students. (Kurniasih 2014: 66-67)[18]

The results of the validity data obtained can be seen in the graph below:

Hasil Validasi

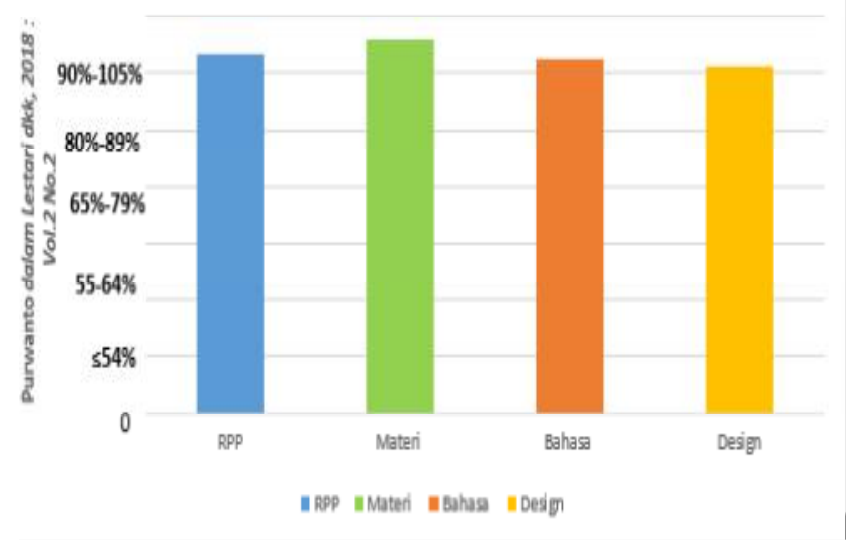

Grafik 1. Validation result 


\section{CONCLUSION}

The Development of Integrated Thematic Student Worksheets (LKPD) with the Discovery Learning Model in integrated thematic learning in class IV Elementary Schools, with theme 8, using the research and devolopment or R\&D method is said to be very valid after carrying out the validation test. The results that have been done by the validator are obtained with the results of the validation in terms of RPP by validator 1 , the average value is $92.5 \%$, namely (very valid), and the RPP by validator 2 obtained the average value is $95 \%$, on the material aspect with V1 average value $97.72 \%$ (very valid) V2 value $95.45 \%$ (Very valid), on the design aspect with a value of $98.07 \%$ (very valid) and on the language aspect an average of $92.5 \%$ (valid ) so that it can be concluded that the development of integrated thematic LKPD with the Discovery Learning model is declared valid for use in the implementation of integrated thematic learning. The results of this study support the research results of (Lorena et al., 2019)[19] that LKPD with discovery learning models is feasible to use, and the results of research (Zulmi \& Akhlis, 2020) that the use of discovery learning-based LKPD is effective in learning [20]

Based on the conclusions of this study, the researcher would like to provide some suggestions, namely as follows: In developing integrated thematic LKPD with the Discovery Learning model it is expected to have a positive impact on integrated thematic learning because it contains a real picture and the discussion is close to the daily lives of students with a learning model that has referred to the 2013 curriculum. Research and development is also needed. further on LKPD on other themes so as to complement the needs of learning resources at school

Validation carried out in this development research shows that the LKPD developed is suitable for use in class IV SD with 4 validators, and the average in terms of RPP by validator 1 obtained an average value of $92.5 \%$, namely (very valid), and RPP by validator 2 obtained an average value of $95 \%$, on the material aspect with V1 an average value of $97.72 \%$ (very valid) V2 a value of $95.45 \%$ (Very valid), on the design aspect with a value of $98.07 \%$ ( very valid) and on the language aspect an average of $92.5 \%$ (valid) and it is hoped that it can be used as an alternative teaching material for teaching in theme 8 , sub-theme 3 in grade IV of elementary school

\section{ACKNOWLEDGMENTS}

The authors are grateful to chief of STKIP ADZKIA, especially to chief of PGSD STKIP Adzkia and many friend are given spirit $\mathrm{n}$ support to make this comes true.

\section{REFERENCES}

[1] Ratih, M., \& Taufina. (2018). THE IMPROVEMENT OF INTEGRATED THEMATIC LEARNING PROCESS BY USING DISCOVERY LEARNING MODEL IN. 1 (1), 253263.

[2] Sulistyorini, S., Harmanto, \& Abidin, Z. (2018). Development of Integrated Thematic Student Worksheets (Lkpd) Integrating Strengthening Character Education (Ppk) and Literacy for Elementary School Students in Semarang City. 9 (1), 21-30.

[3] Rusman. (2015). Integrated Thematic Learning: Theory, Practice and Assessment. Rajawali Pers. 
[4] Melindawati, S. (2019). Development of Integrated Thematic Teaching Materials with Problem Based Learning Model in Class IV SD. Journal of Chemical Information and Modeling, 53 (9), 1689-1699.

[5] Prastowo, A. (2013). Development of Integrated Thematic Teaching Materials. Diva Press.

[6] Ministry of National Education. (2010). Development of Cultural Education and National Character. Curriculum Center.

[7] Ministry of National Education. (2008). Instructional Material Development Guide.

[8] Abidin, A., \& Utami, K. B. (2021). DEVELOPMENT OF STUDENTS 'WORK SHEETS (LKPD) USING THE SEARCH, SOLVE, CREATE, AND SHARE (SSCS) LEARNING MODELS ON THE ABILITY OF SOLVING MATHEMATICS PROBLEMS OF XI IIS SMA EKASAKTI PADANG Anang. 1 (1), 9-20.

[9] Kurniasih, I. (2014). Successfully Implementing the 2013 Curriculum. Said Pena

[10] Rosarina, G., Sudin, A., \& Sujana, A. (2016). Application of Discovery Learning Model to Improve Student Learning Outcomes in Material Change of Forms. Journal of Scientific Pens, 1 (1), 371-380. https://doi.org/10.17509/jpi.v1i1.3043

[11] Putrayasa, \& Syahruddin. (2014). The Influence of Learning Model Discovery Learning and Learning Interest on Student Ipa Learning Outcomes. 2 (1), 11.

[12] Sugiono. (2010). Qualitative and Quantitative Research Methods R \& D. Alfabeta.

[13] Thiagarajan, \& S; Semmel. (1976). Instructional development for training teachers of exceptional children: A sourcebook. Journal of School Psychology, 14 (1), 75. https://doi.org/10.1016/0022-4405(76)90066-2

[14] Trianto. (2011). Designing Innovative-Progressive Learning Models. Golden.

[15] Trianto. (2012). Integrated Thematic Learning Model. PT Bumi Aksara

[16] Arikunto. (2009). Basics of Educational Evaluation. Earth Literacy.

[17] Lestari, L., Alberida, H., \& Rahmi, Y. L. (2018). The Validity and Practicality of the Kingdom Plantae Material Worksheet (LKPD) Based on the Scientific Approach for Class X SMA / MA Students. Journal of Educational Exact (Jep), 2 (2), 170. https://doi.org/10.24036/jep/vol2-iss2/245

[18] Kurniasih, I. (2014). Successfully Implementing the 2013 Curriculum. Said Pena.

[19] Lorena, M., Kasrina, K., \& Yani, A. P. (2019). Development of Lkpd Discovery Learning Model Based on Mangrove Identification in Twa Pantai Panjang, Bengkulu. Diklabio: Journal of Biology Education and Learning, 3 (1), 59-66. https://doi.org/10.33369/diklabio.3.1.59-66

[20] Zulmi, F. A., \& Akhlis, I. (2020). Development of LKPD with EPUB extension based on Discovery Learning to Develop Students' Critical Thinking Skills. 77-83. 